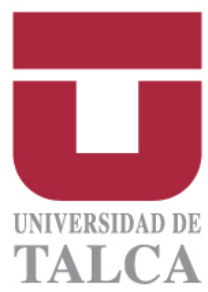

FACE

Facultad de Ciencias Empresariales

\title{
Structural breaks, cointegration and the domestic demand for Chilean wine
}

\author{
Cristián Troncoso Valverde
}

No. 01 Año 2 Mayo 2004

Comité Editor

Javier Pereira Retamales José Rojas Méndez Javier Luis Troncoso Correa

Working Paper Series (ISSN 0717-9545) es una publicación de la Facultad de Ciencias Empresariales de la Universidad de Talca

(Chile)

Director: Germán Lobos Andrade Dirección: FACE - Facultad de Ciencias Empresariales, Universidad de Talca, Av. Lircay s/n, Casilla 721, Talca, Chile. Teléfono: 56-71-200330, Fax: 56-71-201529. Email: globos@utalca.cl

Representante legal: Prof. Dr. Álvaro Rojas Marín, Rector Universidad de Talca. Dirección: 2 Norte 685, Talca, Chile.

Internet

Universidad de Talca (Chile): $\underline{\text { http: //www.utalca.cl }}$ Facultad de Ciencias Empresariales: $\underline{h t t p: / / f a c e . u t a l c a . c l /}$ College of Business Administration: http://digweb.utalca.cl/ingver/ english\%20version.htm FACE Working Paper Series: http://www.face.utalca.wps/

\section{FACE WPS} Working Paper Series

\author{
Universidad de Talca \\ Dos Norte 685 \\ Casilla 721 Talca CHILE \\ http://www.utalca.cl
}




\title{
STRUCTURAL BREAKS, COINTEGRATION AND THE DOMESTIC DEMAND FOR CHILEAN WINE
}

\author{
CRISTIÁN TRONCOSO-VALVERDE ${ }^{1}$
}

\begin{abstract}
The domestic Chilean wine market is examined through the estimation of an error correction model allowing for structural breaks in the cointegrating vector. Our findings support both parameter instability and one structural break in the long-run relationship in 1982 . The wine demand becomes more price-elastic and cross price-elasticity between wine and beer is found to be positive and close to one in the 1983-1998 period. This is in line with the growing substitutability between both wine varieties and wine and beer in Chile during the last two decades. The error correction parameter is found to be negative and highly significant supporting cointegration and suggesting a quick adjustment to long-run equilibrium.
\end{abstract}

JEL Classification: C22, C51, Q11.

Keywords: Error correction models, structural breaks, cointegration, parameter instability.

\section{INTRODUCTION}

During the last two decades, the Chilean wine industry has experienced a strong and accelerate process of internationalization. Investments in new production technologies, more qualified human capital and improved marketing processes are among the main reasons that explain the observed growth rates of $41 \%$ in wine production and $834 \%$ in wine exports during the 1990-2000 period (Schnettler and Rivera, 2003). Notwithstanding, this industry has also suffered from the global tendency of a declining per-capita wine consumption [Anderson et al. (2002); Schnettler and Rivera (2003)]. In fact, Chilean per capita wine consumption has fallen from 68 liters in 1962 to 13 liters in 1993, with some signs of recovery in last years (Costa, 2001). This decline in consumption has been attributed to a change in consumer's tastes, which have shown a strong tendency toward the substitution of wine for other type of alcoholic beverages such as beer. This change in consumer's tastes may be viewed as a consequence of the strategy adopted by most Chilean wineries that

\footnotetext{
${ }^{1}$ Ingeniero Comercial (Universidad de Talca) y Master of Arts in Economics (Concordia University). Profesor Escuela de Ingeniería Comercial, Facultad de Ciencias Empresariales, Universidad de Talca. 2 Norte 685, Casilla 721, Talca, Chile. E-mail: ctroncos@utalca.cl.
} 
focused on producing competitive wine for international markets. Thus, varieties such as Merlot, Chardonay, Carmenère and Syrah that were likely produced only for foreign markets, have reached the popularity of the traditional Cabernet Sauvignon or Sauvignon Blanc in the domestic market (Banda, 2002). In fact, some authors suggest that, as a result of the internationalization of Chilean wineries, domestic consumers have learnt how to 'drink' wine in the sense that consumers now drink less quantity but better quality of wine [c.f. CORFO (1998); Costa (2001) or Schnettler and Rivera (2003)].

Several studies have analyzed the domestic Chilean wine market through the estimation of price and income elasticities. The traditional domestic wine demand function has been specified as a loglinear function of real price of wine, real income and other variables that, according to the economic theory, might affect domestic wine demand. While Mujica and Celedon (1982); Oncken (1983) and Mujica and Oncken (1984) have all estimated both demand and supply functions, Cremaschi (1991) and Martinez (1995) have only considered the demand equation. This research, however, presents conflicting evidence about own-price elasticity. For instance, Mujica and Celedon (1982) estimate an own-price elasticity of -0.01 , whereas Mujica and Oncken (1984) found an estimate of -0.74 with per capita data and -0.84 with aggregate data. Similar disagreement exists for the income elasticity estimates. These vary from 0.031 (Martinez, 1995) to 1.50 (Mujica and Oncken, 1984). Although, from a theoretical point of view, beer may be considered as a substitute of wine, the aforementioned studies have been unable to find evidence supporting this conjecture [c.f. Martinez (1995) and references therein]. This issue appears in contraposition with the claim that consumers have shown a strong tendency to substitute wine for beer during the last two decades.

In what regards the statistical properties of the estimates of the domestic demand model, two properties have been of particular interest. First, the magnitude of the estimates has attracted a great deal of attention. Mujica and Celedon (1982) and Oncken (1983) use these estimates to evaluate the effect that a potential cut in taxes would have over wine consumption and tax evasion. Therefore, accurate estimates are needed for policy evaluation and problems that may induce parameter bias should be accounted for when deciding the econometric technique to be employed. Second, statistical inference over demand estimates has been of central interest [c.f. Mujica and Oncken (1984); Cremaschi (1991); Martinez (1995)]. However, hypothesis testing requires knowing the distribution of the statistic used to test these hypotheses. When variables are nonstationary, traditional test statistics (such as the $\mathrm{t}-$ or the F-statistic) do not follow a normal distribution. In 
light of this, using critical values from student-t or normal distribution for hypothesis testing may conduct the researcher to misleading conclusions.

An implicit assumption made in previous research is the stability of the demand parameters over time. With the exception of Martinez (1995), who recognized this possibility and estimated one set of elasticities for the 1949-1972 period and another set for the 1973-1993 period using dummy variables, no formal attempt has been made in order to check whether demand parameters are stable over time. Under stationarity, it is well known that hypothesis testing needs to be adjust to account for possible structural breaks (Greene, 2000). Although structural breaks have been widely discussed in the context of univariate autoregressive time series with unit roots [c.f. Perron $(1989 ; 1990)$; Zivot and Andrews (1992); Perron and Vogelsang (1992); Christiano (1992); Vogelsang and Perron (1998); Lee and Strazicich (1999); Lee and Strazicich (2002)], discussion about structural breaks and parameter instability in a multivariate nonstationary context is relatively recent. Analysis of structural breaks in the cointegrating parameters has been addressed, among others, by Hansen (1992), Gregory and Hansen (1996) and Kuo (1998).

The purpose of this paper is twofold. First, we analyze short- and long-run demand dynamics through the use of error correction models that are estimated with time-series techniques that address for nonstationarity. Second, we aim to shed some new lights about structural breaks through the Gregory and Hansen (1996) and Bai and Perron's (1998) methodology for the analysis of structural break in cointegrating systems. Parameter instability is analyzed through the instability parameter test proposed by Hansen (1992).

The plan for the rest of the paper is as follows. Next section lays out the basic setup and discusses the econometric methodology employed in estimating the domestic wine demand model. In Section , we carry out the empirical analysis and present our main results. Finally, section concludes the paper with some conclusions and final remarks.

\section{Econometric Methodology}

In this section we lay out the basic model and describe the econometric methodology we use throughout. We begin with a brief discussion about nonstationarity and cointegration. Given our interest in modelling both short- and long-run wine demand dynamics, we distinguish two stages in our methodology. In stage 1 we specify and estimate the long-run model and in stage 2 we estimate the error correction model (ECM). Accordingly, section details the methodology used to obtain 
long-run estimates while section discusses the econometric aspects related to the estimation of the error correction model.

Nonstationarity and Cointegration. A stochastic process is said to be (weakly) stationary if its unconditional mean and variance are constant over time. Nonetheless, it is well known that many economic variables evolve over time and are usually driven by trends that change stochastically over time. This type of processes, called integrated of order one $-I(1)$ in the terminology of Engle and Granger (1987) - are by definition processes whose unconditional mean and variance vary over time. The econometric literature is plenty of devices to determine the order of integration of individual series. Nevertheless, DeJong et al. (1992) and Perron and Ng (1996) have shown power and size misspecifications appear in most of unit root tests when either the root is close to but less than unity or the moving average polynomial of the first differenced series has a large negative root. Following the work of Elliott et al. (1996), Ng and Perron (2001) show that an appropriate selection of the lag truncation in unit-root test together with Generalized Least Squares (GLS) detrended data results in a class of $M$ tests that have good size and power. In the present paper, we follow the Ng and Perron's (2001) suggestion and use the $M^{G L S}$ and the $A D F^{G L S}$ tests to investigate the integration order of the model series.

The above tests assume no structural breaks in the generating process of the series. If such breaks are present, tests such as the $M^{G L S}$ or the $A D F^{G L S}$ lose most of their power [see Vogelsang and Perron (1998) and cites therein]. Since we have reasons to believe that there are breaks in the series, we also test for a unit root using the tests proposed by Zivot and Andrews (1992) and Vogelsang and Perron's (1998) (hereafter the ZA and VP tests respectively). These tests differ from the $M^{G L S}$ or the $A D F^{G L S}$ in that the former consider as the alternative hypothesis a stationary series that fluctuates around a deterministic function with a broken trend. Likewise, the ZA and the VP tests differ from the test originally proposed by Perron in the way the break date is chosen. While Perron (1989) considered the date of break as exogenously given, Zivot and Andrews (1992) and Vogelsang and Perron (1998) make this date endogenous. Notwithstanding, in a recent paper Lee and Strazicich (2001) have pointed out the tendency of these tests to reject the null of a unit root too often. According to these authors, the spurious rejection of the null is caused by the assumption of no breaks under the null made by the ZA and the VP tests. The authors also show that both tests tend to estimate a wrong date for the break, particulary when the magnitude of the break increases. To overcome these problems, Lee and Strazicich (1999; 2002) suggest a Lagrange 
Multiplier (LM) test for the null of a unit root in the presence of structural breaks. Through Monte Carlo simulations, they show that the LM test estimates more accurately the date of break and also avoids the spurious rejection of the ZA and the VP tests. For this reason, we also test for a unit root in model series using this LM test.

As shown by Phillips (1986), serious bias in conventional tests may arise when variables are nonstationary. Phillips show that this bias is due to the fact that distributions of traditional statistics (such as the $\mathrm{t}$ - or the $\mathrm{F}$-statistic) under nonstationary diverge completely from those derived under stationarity. To overcome the problems posed by nonstationarity in a multivariate setting, Engle and Granger (1987) suggest the so-called cointegration analysis. A set of $I(1)$ variables are said to be cointegrated if there exists a linear combination of them that is a stationary stochastic process $^{1}$. Engle and Granger (1987) also demonstrate that a vector of cointegrated variables has always an error correction representation (ECM). This means that it is always possible to construct a linear model in which differences and levels of the variables are used ${ }^{2}$. This class of model has the desirable property of retaining not only short-run information (contained in differences) but also long-run one (contained in the levels). Engle and Granger also show that cointegration implies and is implied by the error correction representation thus clarifying when levels information could legitimately be retained in econometric equations (Hendry, 1986). From a practical point of view, this result is extremely appealing because it enables us to model both short and long-run effects separately in the same model, issue that has not been addressed by the literature on Chilean wine demand estimation.

Long-run Model. In this stage, we specify and estimate the following long-run model:

$$
\begin{aligned}
q_{t} & =\beta_{0}+\beta_{1} p_{t}+\beta_{2} p s_{t}+\beta_{3} y_{t} \\
q_{t} & =\phi^{\prime} x_{t}
\end{aligned}
$$

where $q_{t}$ is the $\log$ of domestic per capita wine consumption, $p_{t}$ is the log of real price of wine, $p s_{t}$ is real price of beer, $y_{t}$ is real GDP per capita and $\phi=\left(\beta_{0}, \beta_{1}, \beta_{2}, \beta_{3}\right)^{\prime}, x_{t}=\left(p_{t}, p s_{t}, y_{t}\right)^{\prime}$. In the light of our previous discussion, the inclusion of the price of beer as one of the regressors in

\footnotetext{
${ }^{1}$ Formally, the component of the vector $x_{t}$ are said to be cointegrated of order $(d, b)$, denoted by $x_{t} \sim C I(d, b)$, if (i) all components in $x_{t}$ are $I(d)$; (ii) there exists a vector $\alpha \neq 0$ so that $z_{t}=\alpha^{\prime} x_{t} \sim I(d-b), b>0$. The vector $\alpha$ is called cointegrating vector (Engle and Granger, 1987).

${ }^{2}$ For further details about error correction models see Davidson et al. (1978)
} 
(1) may seem surprising. However, we conjecture that the lack of significance found in previous studies is mainly due to nonstationary in the variables. Consequently, we include price of beer in domestic wine demand specification and tackle the possible problems posed by nonstationarity in the estimation stage.

Parameters in (1) will be estimated using the Fully Modified (FM) single-equation method of Phillips and Hansen (1990). As shown by Banerjee et al. (1986) the parameters estimated by least squares from a static regression yields super-consistent ${ }^{3}$ estimates of the cointegrating vector, although they may be substantially biased in finite samples. Phillips (1995) show that OLS estimates of any cointegrating relation are second order bias in the sense that their limiting distribution are shifted away from the true parameters, though they are first order unbiased (consistent). This author also argues that this second order bias is due to the fact that OLS regressions are not designed to take into consideration long-run endogeneities in the regressors and it is the presence of such endogeneities which produces this bias. On the contrary, the FM technique is designed to estimate cointegrating relations directly by modifying traditional OLS with non parametric corrections that take into account serial correlation, caused by unit roots, and system endogeneity, caused by cointegration. Furthermore, Phillips (1995) has shown that the FM estimation technique yields t-statistics for parameter estimates which have a normal limiting distribution even in the presence of cointegrated explanatory variables. Thus, standard inferential techniques can be used to test hypothesis on the parameter estimated through the FM technique.

To investigate long-run parameter stability, we apply the econometric methodology proposed by Hansen (1992) and Gregory and Hansen (1996). Hansen considers a set of tests (the SupF-, MeanF- and $L_{c}$-test) which are for the null of a stable cointegrating relationship against several alternatives of interest in the context of cointegrating regression models. He also argues that the lack of cointegration is a special case of the alternative of an unstable intercept so his proposed tests may be viewed as tests for the null of cointegration against the alternative of no cointegration. On the other hand, the residual-based tests of Gregory and Hansen (1996) are extensions to the traditional $A D F-, Z_{\alpha}-$ and $Z_{t}$ - type of tests designed to test the null of no cointegration against the alternative of cointegration in the presence of a possible a regime shift at an unknown time. This econometric technique also allows us to obtain an estimate of the break point that can be used to re-estimated model (1). Nevertheless, Gregory and Hansen's test is designed for a onetime structural break in the cointegrating relationship. Although Kuo (1998) suggests that multiple

\footnotetext{
${ }^{3}$ See for super-consistency of OLS estimates see Stock (1987).
} 
breaks can be accommodated into the alternative hypothesis of these tests, the resulting tests would not be free of nuisance parameter making difficult their application in practice. Instead, we adopt a different approach to address the issue of multiple structural breaks in our domestic wine demand model. We apply the Bai and Perron (1998) methodology (henceforth the BP methodology) as suggested by Morales and Peruga (2002) to investigate the existence of multiple structural breaks in the postulated cointegrating relationship in (1). The BP methodology consists of estimating and testing linear models with multiple structural breaks at an unknown date. The purpose is to estimate unknown regression coefficients together with the break points when $T$ observations are available, i.e., using the entire sample. One advantage of this technique is that the algorithm used to obtain the estimate break points uses at most least squares operations of order $O\left(T^{2}\right)$, while a standard grid search procedure (such as the one used by Gregory and Hansen (1996)) would require least squares operations of order $O\left(T^{m}\right)$, where $m$ is the maximum number of breaks allowed in the sample (Bai and Perron, 2001). This makes the BP algorithm more efficient than standard grid search procedures. Although the BP methodology was developed for stationary regressors, Morales and Peruga (2002) claims that the break point estimated by this methodology is consistent even if regressors are nonstationary. To assess the validity of their claim, Morales and Peruga (2002) run a set of Monte Carlo experiments with nonstationary regressors and obtain the correct break point location in all cases. Therefore, we view the BP methodology as complementary to the Gregory and Hansen (1996) tests.

If we find evidence of parameter instability, the following 'two regime model' will be estimated:

$$
q_{t}=\beta_{0}+\beta_{1} p_{t}+\beta_{2} p s_{t}+\beta_{3} y_{t}+\beta_{4} D U_{t}+\beta_{5} p_{t} D U_{t}+\beta_{6} p s_{t} D U_{t}+\beta_{7} y_{t} D U_{t}+\nu
$$

where $D U_{t}=1(t \geqslant \hat{t}), 1($.$) is the indicator function, \hat{t}$ is the estimated time of the break and $\nu$ is a $I(0)$ process. In case that evidence of multiple structural breaks is found, we re-estimate model (1) adding a dummy variable for each break that is found. The fact that we accommodate multiple breaks with dummy variables obeys to the small sample size we are working with. To model each of these breaks as a regime shift would leave us with too few degrees of freedom for parameter estimation. The residuals obtained from model (1), (2) or this more general model will be used in the second stage and will correspond to deviations from long-run equilibrium.

Error Correction Model. Residual generated from the static model regression in (1), model (2) or model (1) with dummies represents deviations from long-run equilibrium and can be used 
to estimate the short-run dynamics of domestic wine demand using the following error-correction model,

$$
\Delta q_{t}=\gamma_{0}+\sum_{i=1}^{k} \gamma_{i} \Delta q_{t-i}+\sum_{i=0}^{k} \zeta_{i} \Delta p_{t-i}+\sum_{i=0}^{k} \theta_{i} \Delta p s_{t-i}+\sum_{i=0}^{k} \psi_{i} \Delta y_{t-i}+\varphi e c m_{t-1}+v_{t}
$$

where $e c m_{t-1}$ is the residual from estimating (1) or (2) using FMOLS and $v_{t} \backsim i i d(0, \sigma)$. The model in (3) is estimated via Least Squares (LS). The lag length, $k$, is chosen by two methods. First, we look for the value of $k$ that minimizes the Bayesian information criterium (BIC) and the Akaike information criterion (AIK) from LS estimation. Second, we test sequentially the significance of the individual parameters using standard t-tests until a parsimonious model is obtained. In both cases, the maximum lag length considered for model selection is 4 . Of special interest is the estimate of the error correction parameter, $\varphi$, in model (3). This parameter is important because it measures the speed of adjustment of the model to disequilibrating shocks. This coefficient is expected to be negative and large values will indicate faster adjustment to long-run equilibrium given economic shocks. Following the results of Banerjee et al. (1990) and Kremers et al. (1992), the error correction parameter can also be viewed as a cointegration test. According to these authors, this test is more powerful than the cointegration tests based on the residuals of a static cointegrating regression and also performs better in finite samples. Since the cointegrating vector is estimated before the ECM, traditional critical values can be used to test the significance of the $\varphi$ parameter.

\section{EMPIRICAL RESULTS}

In this section we report and discuss the results obtained from applying the econometric methodology discussed in the previous section. We begin by analyzing the time-series properties of each series in terms of their integration order. After this is done, the long-run model in (1) is estimated and parameter instability test are conducted. Conditional on the results of these tests, we estimate model (2), model (1) with dummies, or simply proceed with residuals from (1) in the ECM estimation stage. Finally, model (3) is estimated and short-run elasticities are obtained.

The data set covers the 1949-1998 period and has been obtained from the National Statistical Bureau $\left(\mathrm{INE}^{4}\right)$, Minister of Agriculture ${ }^{5}$ and the Central Bank of Chile. All prices are in real terms. A more detailed description of the variables used in this study can be found in Appendix 1.

\footnotetext{
${ }^{4}$ Instituto Nacional de Estadísticas, Chile.

${ }^{5}$ Servicio Agrícola y Ganadero, SAG. Ministerio de Agricultura, Chile.
} 
Testing for a unit root. To analyze the integration order of each model series, we apply the unit root tests outlined in section. These results are reported in Table 2 and Table 3. All tests were conducted using GAUSS 3.6.17 .

For tests without structural breaks, critical values can be obtained from Ng and Perron (2001). Using the $5 \%$ critical values, we can not reject the null of a unit root for any individual series. In the case of unit root tests with structural breaks, critical values can be obtained from Zivot and Andrews (1992), Vogelsang and Perron (1998) and Lee and Strazicich (1999) for the Min LM test. Model A corresponds to the 'crash model'; Model B to the 'changing growth model' and Model C to the 'crash/changing model' of Vogelsang and Perron (1998). Based on the results in Table 3, we do not reject the null of a unit root for almost all individual series using conventional critical values. For the case of the price of beer series the evidence is not conclusive. This is particulary evident when we look at the results from the Min LM test. These results appear to favor the alternative of trending stationarity under both nulls (the crash and crash/changing trend model). However, Lee and Strazicich (1999) report critical values based on simulations for a sample size of 100 and assuming that the break occurs in the middle of the sample. Moreover, the calculated t-ratio for model A is close to their $1 \%$ critical value (-4.30). Nonetheless, the estimated break point obtained by the LM test should be more accurate that the estimate break of Zivot and Andrews or Vogelsang and Perron. As such, we may see Lee and Strazicich's tests as a test for determining the correct break point in each model series. Based on the evidence presented above, we conclude that the model series can be regarded as nonstationary variables integrated of order one.

Long-run empirical model. Having characterized the model series in terms of their integration order, we estimate the long-run model in (1) using the FM single-equation techniques of Phillips and Hansen (1990). Table 4 reports the results.

Based on the information presented in Table 5, the null of cointegration in model (1) is not rejected using $1 \%$ critical values. This is so because the Hansen's $L_{c}$ test can be seen as a test for the null of cointegration against the alternative of no cointegration. Alternatively, the SupF tests is helpful in discovering whether there was a swift shift in regime in (1). The p-value for this test indicates that this is indeed the case. Yet a caveat regarding the SupF tests is in order here. The fact that this test rejects the null of a stable cointegrating relationship does not necessarily mean that we have to conclude, based on this piece of evidence alone, that there are two cointegrating regimes

\footnotetext{
${ }^{6}$ Algorithms used for conducting unit root tests are available upon author's request.
} 
which shifted at a particular point in time. The evidence only suggests that wine consumption, price of wine, price of beer and per-capita GDP are cointegrated, but the logarithm approximation used in (1) appears unstable or may be a misspecificated model representation. Notwithstanding, results from regressing model (1) without taking variables in logarithm only improves the p-value for the $L_{c}$ test (it becomes 0.13059040 ) but still suggests that this relationship is not stable over time $^{7}$.

To further investigate possible regime shifts in (1), we use the information provided by the Gregory and Hansen's residual-based test (Table 6). The fact that it is possible to reject the null of a stable cointegrating relationship at $5 \%$ only for the level shift with trend $(\mathrm{C} / \mathrm{T})$ model may be due to the little information that can be obtained from a sample of 50 observations. In fact, critical values are only asymptotic approximations obtained via Monte Carlo simulations and hypothesis rejection may well be due to finite sample bias, as pointed out by Gregory and Hansen (1996). Furthermore, computed statistics for Model $\mathrm{C}$ are not far from the corresponding critical values. Bai and Perron's methodology, nonetheless, suggests the existence of one break in the postulated long-run relationship, based on the sequential procedure, the Bayesian (BIC) and the Liu et al. (1997) (LWZ) information criteria. The estimated break point occurs at $t=1982^{8}$. Notice how close this estimate is from the one obtained by Gregory and Hansen's when the alternative is a cointegrating regime shift model (C/S model of Gregory and Hansen). Indeed, Mujica and Oncken (1984) argues that the Chilean wine industry experienced a major crisis during the 80s which began in 1981 and may be attributed to several reasons. Among these reasons, the authors mention the Chilean recession at the beginning of the 80 s, the liberalization of several restrictions prevalent in the Chilean wine market until 1979 and some changes in the tax structure of this sector. Before 1979, wine production was restricted to sixty liters per-capita as maximum per firm (Martinez, 1995) and wine could be produced only with certain types of grapevines. By the end of 1979, practically all these regulations were eliminated and some changes in supervision and control of tax collection were introduced. In light of this, it appears as very reasonable to expect parameter instability and a structural change in domestic wine demand in the beginning of the 80s. Hence, based on this information, the results from instability tests of Hansen (1992) and the residual-based test of

\footnotetext{
${ }^{7}$ The results from running model (1) with variables in levels are not reported here but are available upon the author's request.

${ }^{8}$ Estimation of break dates and parameters were conducted using the companion GAUSS algorithm of Bai and Perron (2001).
} 
Gregory and Hansen (1996), we suggest the existence of parameter instability and a shift in regime at $t=1982$ in the postulate long-run model in (1).

As discussed in section, the presence of structural breaks and parameter instability in (1) requires the estimation of model (2). We estimate this model by the FM estimation technique. However, we further investigate the effect of this regime shift in the postulated cointegrating relationship by applying the Bai and Perron (1998) algorithm in which date of break and model parameters are estimated altogether. We are aware that a partition of the sample at $t=1982$ may lead to a lost of efficiency in the FM estimators given the small number of elements in each subsample. However, we employ the FM technique because it is designed for nonstationary regressors whereas the BP estimation technique is not. Table 7 exhibits these results.

From Table 7, two set of elasticities can be computed. For the 1949-1982 period, long-run elasticities are simply the parameter estimates $\beta_{i}, i=0,3$. The 1983-1998 elasticities are obtained by adding to the corresponding $\beta_{i}, i=0,3$, the value of $\beta_{j}, i=4,7$. In other words, long-run price elasticity for the $1983-1998$ period is equal to $\beta_{1}+\beta_{5}=-0.6341$. The remaining elasticities are compute likewise and are reported in Table 8.

As a first issue, notice the difference arising between 1949-1982 and the 1983-1998 own-price elasticity. According to the figures in Table 7 and 8, the domestic wine demand becomes more elastic after 1982. This result is not surprising if we consider the growth in wine varieties produced in Chile during the last two decades. By the end of the 70s, the Chilean wine industry adopted as part of its internationalization process a strategy known as 'the best value' or 'value for money' strategy in order to compete with other wine producers in the demanding international wine markets (Fuentes and Vargas, 2002). To this aim, Chilean wine producers focussed on the production of premium wine in detriment of the lower quality wine supplied to the domestic market at that time. This increase in wine varieties in turn implied an expansion of domestic wine market leading to a more segmented market with consumers willing to pay higher prices for better quality (Banda, 2002; Schnettler and Rivera, 2003). Thus, to account for this higher substitutability between wine varieties, the aggregated domestic wine demand became more elastic.

Another issue that is worth discussing is the role played by beer when structural breaks are allowed in demand estimation. When a stable relationship is estimated (Table 4), price of beer turns out to be significant but with negative sign. In light of this result, we would be tempted to conclude that wine and beer are complementary goods instead of substitutes, as suggested by previous research 
in domestic wine demand. Notwithstanding, this conclusion changes when structural breaks are allowed. The 1949-1982 estimate parameters indicate that during this period beer is not statistically different from zero and from a econometric point of view its exclusion from domestic wine demand specification would be justified. However, the 1983-1998 results show a totally different picture. First, cross price-elasticity turns out to be positive and second, the magnitude of this elasticity is close to one and significant at a $10 \%$ level of confidence ${ }^{9}$. Consequently, the idea that beer has become an important substitute for wine consumption in Chile during last years finds some supporting evidence on these results.

A final issue worth to be discussed is the magnitude and significance of the income elasticity estimate. Contrary to previous findings, income elasticity turned out to be negative both when a stable relationship is estimated (Table 4) and when structural breaks are allowed (Table 7). In the first case, we find an income elasticity of -1.3 , whereas in the second case this estimate fluctuates between -0.14 and -0.30 for the 1949-1982 period and between -1.72 and -2.20 for the 1983-1998 period. Similarly to the case of the own price-elasticity, these results may be reflecting the fact that Chilean wine consumers have become more demanding in what regards wine quality but have become 'soft drinkers' in what regards wine quantity. Indeed, Schnettler and Rivera (2003) claim that Chilean wine consumers ingest less quantity but better quality of wine. If we add to this fact the overall increase in per capita GDP during this period, it is totally expectable to find a negative income elasticity when both wine consumption and GDP are considered in aggregate terms.

Error correction model results. As outlined in section we investigate the short-run dynamics of domestic wine demand by estimating the error correction model in (3). The lag length was selected using two methods: the significance of the lagged terms and the minimization of the Akaike and the Bayesian information criteria. Results diverge in lag length selection but turn out to be similar in terms of estimate parameters. The estimates for the ECM in (3) using a lag length of 0 and a lag length of 1 are reported in Table 9.

Several conclusions emerge from Table 9. First, as expected the own-price elasticity is negative and significant at $5 \%$ level of confidence. Second, cross-price elasticity turns out to be negative but very close to zero. Thus, based purely on the short-run results we are lead to conclude that beer acts as a complement instead of substitute, although its effect in short-run demand dynamics is not significant. Third, income parameter turns out to be positive but not statistically significant for

\footnotetext{
${ }^{9}$ The t-ratio for this elasticity is 1.7876 .
} 
all model regressions. This result may be due to small sample problems, model misspecification or problems with the proxy chosen for representing consumer's income. Nonetheless, we could think of domestic wine demand as a normal good in the short-run even if the estimate parameter turned out not to be statistically significant. Finally, the error correction parameter is found to be negative and highly significant regardless the lag length employed in the estimation of (3). As mentioned in section, the error correction term can be regarded as a cointegration test. Using critical values from a normal distribution, the reported t-statistic is, in all cases, highly significant. The same conclusion is obtained if we use the non standard critical values of Ericson and MacKinnon (2002). In this last case, the p-values for the t-statistics are 0.0134 when a lag of 0 is used and 0.0139 when model lag is 1 . Therefore, the significance of the computed error correction term indicates that model variables are indeed cointegrated. Regarding the value of the error correction parameter, we can claim the existence of a fast adjustment to long-run equilibrium. This is because greater values of this parameter implies faster adjustments to long-run equilibrium. This appears indeed to be the case for domestic wine demand.

\section{Conclusions and Final Remarks}

This paper examines the domestic Chilean wine market through the estimation of short- and long-run elasticities using time-series techniques that address the problems posed by nonstationary regressors. We also investigate long-run parameter instability and estimate a domestic wine demand model allowing for structural breaks in the cointegrating vector. Results from instability tests support both unstable cointegrating parameters and the existence of one break in 1982. From the estimated long-run two regime shift model, domestic wine demand is more price elastic after 1982. This result is not surprising if we consider the higher substitutability between wine varieties observed in Chile during the last two decades. When structural breaks are accounted for, cross price-elasticity between wine and beer turns out to be positive with a value close to one for the 1983-1998 period. This result is in line with the observed growing importance of beer as a substitute for wine consumption in Chile during last years. Results from the ECM suggest that domestic wine demand is price inelastic and that beer acts as a complement instead of substitute, although its effect in short-run demand dynamics is not significant. In what regards income elasticity estimates, our findings suggest that wine is a normal good in the short-run, although income estimate is not statistically significant at a $10 \%$ level of confidence. Finally, the error correction parameter turns out to be negative and highly significant regardless the lag length employed in the estimation of the 
ECM. This result supports the existence of a cointegrating relationship in domestic wine demand and points toward a fast adjustment to long-run equilibrium given economic shocks in the domestic wine market.

\section{ACKNOWLEDGEMENTS}

I would like to thank the members of the Department of Economics at Concordia University, Montreal, Canada, where part of this research was done while I was a graduate student. I would also like to thank Ereney Hadjigeorgalis, Pablo Morán and Rodrigo Saens for their their valuable comments and suggestions. Of course, all the errors cointained in this paper are my own responsibility. 


\section{REFERENCES}

Anderson, K., Norman, D. and Wittwer, G. (2002), Globalization of the World's Wine Markets, Discussion paper 3169, Centre for Economic Policy Research, London, UK.

Bai, J. and Perron, P. (1998), 'Estimating and Testing Linear Models with Multiple Structural Changes', Econometrica 66, $47-78$.

Bai, J. and Perron, P. (2001), Computation and Analysis of Multiple Structural Change Models, Working paper, Department of Economics, Boston University, USA.

Banda, R. (2002), 'Vinos. Profetas en su Tierra', Revista Publimark 161, 54-58.

Banerjee, A., Dolado, J., Hendry, D. and Smith, G. (1986), 'Exploring Equilibrium Relationships in Econometrics through Statict Models: some Monte Carlo evidence', Oxford Bulletin of Economics and Statistics 48, 523-277.

Banerjee, A., Galbraith, J. W. and Dolado, J. (1990), 'Dynamic Specification and Linear Transformation of the Autoregressive-Distributed Lag Model', Oxford Bulletin of Economics and Statistics 52, 95-104.

Christiano, L. (1992), 'Searching for a break in GNP', Journal of Business \& Economic Statistics 10, $237-250$.

CORFO (1998), Evolución y proyecciones de la producción vitivinícola. Technical Report. Corporación de Fomento a la Producción, CORFO, Chile. Available at http://www.corfo.cl/publicaciones/docs/anexo1.rtf.

Costa, V. (2001), La Vitivinicultura Mundial y la situación Chilena en 2001. Technical Report. Servicio Agrícola y Ganadero, S.A.G. Ministry of Agriculture, Chile. Available at http://www.sag.gob.cl.

Cremaschi, C. (1991), Análisis Comercial y Econométrico del Mercado Vitivinícola Chileno: un Enfoque Internacional, Unpublished manuscript, Facultad de Agronomía, Pontificia Universidad Católica de Chile, Chile.

Davidson, J., Hendry, D., Srba, F. and Yeo, S. (1978), 'Econometric Modelling of the Aggregate Time-Series Relationship between Consumers' expenditure and Income in the United Kingdom', Economic Journal 88, 661-92.

DeJong, D., Nankervis, J., Savin, E. and Whiteman, C. (1992), 'The Power Problem of Unit Root Tests in Time Series with Autorregressive Errors', Journal of Econometrics 53, 323-43.

Elliott, G., Rothenberg, T. and Stock, J. (1996), 'Efficient Tests for an Autoregressive Unit Root', Econometrica 64, 813-36.

Engle, R. and Granger, C. (1987), 'Co-integration and Eror-Correction Representations, Estimation and Testing', Econometrica 55, 251-76.

Ericson, N. and MacKinnon, J. (2002), ‘Distribution for Error-Correction Tests for Cointegration', Econometrics Journal 5, 285-318.

Fuentes, P. and Vargas, G. (2002), 'Vino Chileno: Crisis y Crecimiento', Revista Agronomia y Forestal UC 14, 15-19. Greene, H. (2000), Econometric Analyis, 4th edn, Prentice Hall.

Gregory, A. and Hansen, B. (1996), 'Residual-based tests for cointegration in models with regime shifts', Journal of Econometrics 70, 99-126.

Hansen, B. (1992), 'Tests for parameter instability in regressions with I(1) processes', Journal of Business EJ Economic Statistics 10, 321-335.

Hendry, D. F. (1986), 'Econometric Modelling with Cointegrated Variables: An Overview', Oxford Bulletin of Economics and Statistics 48, 201-12. 
Kremers, J., Ericsson, N. R. and Dolado, J. J. (1992), 'The Power of Cointegration Tests', Oxford Bulletin of Economics and Statistics 54, 325-48.

Kuo, B. (1998), 'Test for partial parameters stability in regressions with I(1) processes', Journal of Econometrics 86, 337-368.

Lee, J. and Strazicich (2001), 'Break point estimation and spurious rejections with endogenous unit root tests', Oxford Bulletin of Economics and Statistics 63, 535-558.

Lee, J. and Strazicich, M. (1999), Minimum LM Unit Root Test with One Structural Breaks, Discussion paper 9932, Department of Economics, University of Central Florida, USA.

Lee, J. and Strazicich, M. (2002), Minimum LM Unit Root Test with Two Structural Breaks, Discussion paper check 02-20, Department of Economics, University of Central Florida, USA.

Liu, J., Wu, S. and Zidek, J. (1997), 'On Segmented Multivariate Regression', Statistica Sinica 7, 497-525.

MacKinnon, J. (1996), 'Numerical Distribution Functions for Unit Root and Cointegration tests', Journal of Applied Econometrics 11, 601-18.

Martinez, J. (1995), Análisis de la evolución de las elasticidades de la demanda de vino, Unpublished manuscript, Departamento de Economía Agraria, Pontificia Universidad Católica de Chile, Chile.

Morales, A. and Peruga, R. (2002), 'Purchasing Power Parity: Error Correction Models and Structural Breaks', Open Economies Review 13, 5-26.

Mujica, R. and Celedon, C. (1982), Efecto tributario de la eliminación del iva adicional a los alcoholes, Documento de trabajo nro.87, Instituto de Economía, Pontificia Universidad Católica de Chile, Chile.

Mujica, R. and Oncken, H. (1984), 'Análisis Econométrico de la Industria Vitivinícola en Chile', Latin American Journal of Economics (Cuadernos de Economía) 21, 315-27.

Ng, S. and Perron, P. (2001), 'Lag Length Selection and the Construction of Unit Root Tests with Good Size and Power', Econometrica 69, 1519-54.

Oncken, G. (1983), Un modelo económetrico de la industria vitivincola: Una aplicación en el impuesto adicional al vino (1948-1981), Unpublished manuscript, Departamento de Economía Agraria, Pontificia Universidad Católica de Chile, Chile.

Pavez, D. (2002), Efectos de la posible alza del IVA adicional a los alcoholes sobre la industria vitivinícola, Unpublished manuscript, Facultad de Ciencias Económicas y Administrativas, Universidad de Chile, Chile.

Perron, P. (1989), 'The Great Crash, the Oil Price Shock, and the Unit Root Hypothesis', Econometrica 57, $1361-401$.

Perron, P. (1990), ‘Testing for a Unit Root in a Times Series with a Changing Mean', Journal of Business 63 Economic Statistics 8, 153-162.

Perron, P. and Ng, S. (1996), 'Useful Modifications to Unit root tests with dependent Errors and their Local Asymptotic Properties', Review of Economic Studies 63, 435-465.

Perron, P. and Vogelsang, T. (1992), 'Nonstationarity and level shifts with application to purchasing power parity', Journal of Business \& Economic Statistics 10, 301-320.

Phillips, P. (1986), 'Understanding Spurious Regressions in Econometrics', Journal of Econometrics 33, 311-40.

Phillips, P. (1995), 'Fully Modified Least Squares and Vector Autoregression', Econometrica 63, 1023-1078. 
Phillips, P. and Hansen, B. (1990), 'Statistical Inference in Instrumental Variables Regressions with I(1) Processes', Review of Economic Studies 57, 99-125.

Schnettler, B. and Rivera, A. (2003), 'Características del proceso de desición de compra de vino en la IX Región de la Araucanía, Chile', Ciencias e Investigación Agraria 30, 1-14.

Stock, J. (1987), 'Asymptotic Properties of Least Squares Estimators of Cointegrating Vectors', Econometrica $\mathbf{5 5}(5), 1035-56$.

Vogelsang, T. and Perron, P. (1998), 'Aditional tests for a unit roots allowing for a break in the trend function at an unknown time', International Economic Review 39, 1073-1100.

Zivot, E. and Andrews, D. (1992), 'Further evidence on the great crash, the oil price shock, and the unit root hypothesis', Journal of Business 85 Economic Statistics 10, 251-270. 
$q_{t}$ : Logarithm of per capita wine consumption. Total wine consumption is defined as the difference between total wine production minus total wine exports. Data on wine production and wine exports were obtained from the Servicio Agrícola y Ganadero, S.A.G., Department of Alcoholic Beverages, Ministry of Agriculture, Chile. Data on population were obtained from Instituto Nacional de Estadísticas, INE. (Chilean Bureau of Statistics).

$p_{t}, p s_{t}$ : Logarithm of real price of wine and real price of beer per liter, respectively. $p_{t}$ corresponds to the 'current price of wine' item, while $p s_{t}$ is the price of beer item in the consumer price survey applied by the Instituto Nacional de Estadísticas, INE. (Chilean Bureau of Statistics). Both price series are deflated using the consumer price index published by the INE.

$y_{t}$ : Logarithm of real per capita GDP. GDP series was obtained from different numbers of the Economic Bulletin published by the Central Bank of Chile. Data on total population was obtained from the Instituto Nacional de Estadisticas, INE. (Chilean Bureau of Statistics). This series has been deflacted using the implicit GDP deflactor published by the Central Bank of Chile. 
TABLE 1. Wine and beer consumption in Chile.

Data on wine consumption were obtained from the Department of Alcoholic beverages, S.A.G., Chilean Ministry of Agriculture. Beer consumption data were obtained from Pavez (2002). All data are in per capita terms.

\begin{tabular}{|ccc|ccc|}
\hline Year & $\begin{array}{c}\text { Wine } \\
(\text { Liters })\end{array}$ & $\begin{array}{c}\text { Beer } \\
(\text { Liters })\end{array}$ & Year & $\begin{array}{c}\text { Wine } \\
\text { (Liters) }\end{array}$ & $\begin{array}{c}\text { Beer } \\
\text { (Liters) }\end{array}$ \\
\hline 1971 & 51.90 & 9.00 & 1986 & 36.00 & 20.80 \\
1972 & 59.00 & 11.00 & 1987 & 32.00 & 21.28 \\
1973 & 53.50 & 9.00 & 1988 & 30.00 & 21.83 \\
1974 & 45.90 & 11.00 & 1989 & 28.00 & 21.19 \\
1975 & 41.90 & 12.00 & 1990 & 26.00 & 20.26 \\
1976 & 45.10 & 13.00 & 1991 & 23.00 & 21.25 \\
1977 & 49.20 & 14.00 & 1992 & 18.00 & 26.90 \\
1978 & 45.40 & 14.66 & 1993 & 13.00 & 28.86 \\
1979 & 44.10 & 16.47 & 1994 & 18.00 & 27.81 \\
1980 & 42.70 & 17.08 & 1995 & 15.00 & 28.50 \\
1981 & 41.70 & 15.88 & 1996 & 15.80 & 27.72 \\
1982 & 40.10 & 15.31 & 1997 & 13.10 & 27.54 \\
1983 & 38.80 & 15.26 & 1998 & 18.30 & 27.43 \\
1984 & 37.50 & 15.96 & 1999 & 17.00 & 26.05 \\
1985 & 36.90 & 17.02 & 2000 & 17.80 & 26.62 \\
\hline
\end{tabular}


TABLE 2. $M$ class of unit-root tests.

These unit-root test correspond to those suggested by Ng and Perron (2001). Asymptotic critical values for the $M Z_{a}, M Z_{t}$ and the $A D F^{G L S}$ tests can be found in Table I of $\mathrm{Ng}$ and Perron (2001, p. 1524). Critical values for the Phillips-Perron $Z_{a}$ test can be obtained from MacKinnon (1996).

\begin{tabular}{|ccccc|}
\hline Tests & $q_{t}$ & $p_{t}$ & $p s_{t}$ & $y_{t}$ \\
\hline Phillips-Perron $Z_{a}$ & -8.456 & -13.578 & -12.625 & -2.714 \\
Modified Phillips-Perron $M Z_{a}$ & -7.373 & -11.539 & -10.739 & -2.560 \\
Modified Phillips-Perron $M Z_{t}$ & -1.882 & -2.382 & -2.296 & -0.833 \\
$A D F^{G L S}$ & -2.159 & -2.803 & -2.700 & -0.883 \\
\hline
\end{tabular}

TABLE 3. Unit-root tests with broken trend.

These unit-root test corresponds to the Min $t_{\alpha}$ of Zivot and Andrews (1992); the Min $t_{\alpha}$ for innovational (IO) and additive models (AO) of Vogelsang and Perron (1998); and the Min LM test of Lee and Strazicich (1999). Critical values can be found at these papers. Model A corresponds to the 'crash model'; Model B to the 'changing growth model' and Model $\mathrm{C}$ to the 'crash/changing model', as defined in Vogelsang and Perron (1998). (***), (**), (*) means significance at 1, 5 and $10 \%$.

\begin{tabular}{|ccc|cc|ccc|cc|}
\hline Series & \multicolumn{2}{|c|}{ ZA Min $t_{\alpha}$} & \multicolumn{2}{c|}{ IO Min $t_{\alpha}$} & \multicolumn{3}{c|}{ AO Min $t_{\alpha}$} & \multicolumn{2}{c|}{ Min LM test } \\
\hline & Model A & Model B & Model A & Model C & Model A & Model B & Model C & Model A & Model B \\
\hline$q_{t}$ & -2.94 & $-4.63^{* *}$ & -3.32 & -4.80 & -3.05 & $-4.47^{* *}$ & -4.56 & -2.33 & -3.41 \\
$p_{t}$ & -4.19 & $-4.42^{* *}$ & -4.90 & -4.94 & -4.52 & $-4.16^{* *}$ & -4.89 & -4.38 & -4.48 \\
$p s_{t}$ & -3.93 & $-6.66^{* * *}$ & $-6.53^{* * *}$ & $-8.16^{* * *}$ & $-6.47^{* * *}$ & $-4.69^{* *}$ & $-7.04^{* * *}$ & -4.86 & -7.83 \\
$y_{t}$ & -2.94 & $-4.93^{* * *}$ & -3.13 & -5.06 & -2.12 & -2.79 & -2.95 & -1.74 & -3.99 \\
\hline
\end{tabular}

TABLE 4. Fully-Modified Parameter Estimates.

These results correspond to the estimation of the following model: $q_{t}=\beta_{0}+\beta_{1} p_{t}+\beta_{2} p s_{t}+\beta_{3} y_{t}$ by the Fully Modified single-equation technique of Phillips and Hansen $(1990)$. $\left({ }^{* *}\right),(* *),(*)$ means significance at 1,5 and $10 \%$.

\begin{tabular}{|ccccc|}
\hline & $\beta_{0}$ & $\beta_{1}$ & $\beta_{2}$ & $\beta_{3}$ \\
\hline Estimate & 22.3108 & 0.0485 & -0.1904 & -1.2993 \\
Standard Error & 2.5812 & 0.1161 & 0.0719 & 0.2155 \\
t-ratio & $8.6430^{* * *}$ & 0.4183 & $-2.6492^{* *}$ & $-6.0286^{* * *}$ \\
\hline
\end{tabular}




\section{TABLE 5. Instability test results.}

This table exhibits the results from the instability test of Hansen (1992).

\begin{tabular}{|ccc|}
\hline Tests & Statistic & p-value \\
\hline LC test & 0.9214 & 0.0340 \\
MeanF test & 271.2026 & 0.0100 \\
SupF test & 908.0381 & 0.0100 \\
\hline
\end{tabular}

\section{TABLE 6. Residual-based tests.}

This table exhibits the results from the residual-based test of Gregory and Hansen (1996). $(* * *),(* *),(*)$ means significance at 1,5 and $10 \%$.

\begin{tabular}{|cccccc|}
\hline Model & $A D F$ & $\hat{t}$ & $Z_{t}$ & $Z_{\alpha}$ & $\hat{t}$ \\
\hline Level shift (C) & -4.9784 & 1989 & $-5.0843563^{*}$ & -36.468185 & 1989 \\
Level shift/trend (C/T) & $-5.6959^{* *}$ & 1990 & $-5.7621122^{* *}$ & -41.003151 & 1990 \\
Regime shift (C/S) & -5.5404 & 1984 & -5.3194256 & -40.975469 & 1981 \\
\hline
\end{tabular}

\section{TABLE 7. Two-regime model estimation results}

This table shows the results from estimating the following two-regime model $q_{t}=\beta_{0}+\beta_{1} p_{t}+\beta_{2} p s_{t}+$ $\beta_{3} y_{t}+\beta_{4} D U_{t}+\beta_{5} p_{t} D U_{t}+\beta_{6} p s_{t} D U_{t}+\beta_{7} y_{t} D U_{t}+\nu$; where $D U_{t}=1(t>1982)$ is the indicator function. $\left({ }^{* *}\right),\left({ }^{* *}\right),\left({ }^{*}\right)$ means significance at 1,5 and $10 \%$.

\begin{tabular}{|cccc|ccc|}
\hline & \multicolumn{3}{c|}{ Bai and Perron estimates } & \multicolumn{3}{c|}{ Fully Modified estimates } \\
\hline Parameter & Estimates & Std Error & t-ratio & Estimates & Std Error & t-ratio \\
\hline$\beta_{0}$ & 6.6616 & 2.6205 & $2.5418^{* * *}$ & 8.7035 & 2.0902 & $4.1640^{* * *}$ \\
$\beta_{1}$ & -0.1318 & 0.0642 & $-2.0520^{* *}$ & -0.0762 & 0.0496 & $-1.5363^{*}$ \\
$\beta_{2}$ & -0.0187 & 0.0412 & -0.4545 & -0.0391 & 0.0319 & -1.2257 \\
$\beta_{3}$ & -0.1395 & 0.2008 & -0.6948 & -0.3041 & 0.1597 & $-1.9042^{* *}$ \\
$\beta_{4}$ & 27.7596 & 5.5152 & $5.0333^{* * *}$ & 16.6804 & 2.0902 & $7.9803^{* * *}$ \\
$\beta_{5}$ & -0.5023 & 0.2520 & $-1.9936^{* *}$ & -0.4035 & 0.2009 & $-2.0085^{* *}$ \\
$\beta_{6}$ & 1.5948 & 1.1412 & $1.3975^{*}$ & 1.1288 & 0.8823 & 1.2794 \\
$\beta_{7}$ & -2.0566 & 0.7055 & $-2.9151^{* * *}$ & -1.4203 & 0.5680 & $-2.5005^{* *}$ \\
\hline
\end{tabular}




\section{TABLE 8. Domestic wine demand elasticities.}

For the 1949-1982 period, elasticities correspond to the parameter estimates $\beta_{i}, i=0,3$. The $1983-$ 1998 elasticities are obtained by adding to the corresponding $\beta_{i}, i=0,3$, the value of $\beta_{j}, j=4,7$. Thus, the 1983-1998's own-price elasticity is equal to $\beta_{1}+\beta_{5}=-0.6341$. The remaining elasticities are compute likewise. $\mathrm{t}-$ ratios were computed as follows: $t\left(\beta_{i}+\beta_{j}\right)=\frac{\left(\beta_{i}+\beta_{j}\right)}{\sqrt{\operatorname{Var}\left(\beta_{i}+\beta_{j}\right)}} \cdot\left({ }^{* * *}\right),\left({ }^{* *}\right),\left(^{*}\right)$ means significance at 1, 5 and $10 \%$.

\begin{tabular}{|lrr|rr|}
\hline & \multicolumn{2}{c|}{ Bai and Perron estimates } & \multicolumn{2}{c|}{ Fully Modified estimates } \\
\hline & $1949-1982$ & $1983-1998$ & $1949-1982$ & $1983-1998$ \\
\hline Own-price & $-0.1318^{* *}$ & $-0.6341^{* * *}$ & $-0.0762^{*}$ & $-0.4797^{* * *}$ \\
Cross-price & -0.0187 & $1.5761^{*}$ & -0.0391 & $1.0897^{*}$ \\
Income & -0.1395 & $-2.1961^{* * *}$ & $-0.3041^{* *}$ & $-1.7244^{* * *}$ \\
\hline
\end{tabular}

TABLE 9. Error correction model results.

$\left({ }^{* *}\right),\left({ }^{* *}\right),\left({ }^{*}\right)$ means significance at 1,5 and $10 \%$.

\begin{tabular}{|lrrr|rrr|}
\hline & \multicolumn{3}{c|}{ Lag length :0 } & \multicolumn{3}{c|}{ Lag length :1 } \\
\hline Parameter & Estimate & Std. Error & t-ratio & Estimate & Std. Error & t-ratio \\
\hline$\Delta p_{t}$ & -0.1640 & 0.0901 & $-1.8212^{* *}$ & -0.1640 & 0.1001 & $-1.6381^{* *}$ \\
$\Delta p s_{t}$ & -0.0842 & 0.0481 & $-1.7522^{* *}$ & -0.0881 & 0.0505 & $-1.7449^{* *}$ \\
$\Delta y_{t}$ & 0.1442 & 0.3600 & 0.4005 & 0.0687 & 0.4066 & 0.1690 \\
$e c m_{-1}$ & -0.8042 & 0.1812 & $-4.4390^{* * *}$ & -0.9181 & 0.2488 & $-3.6909^{* * *}$ \\
\hline
\end{tabular}




\section{Normas para la Presentación de Trabajos}

Working Paper Series (WPS) de la Facultad de Ciencias Empresariales de la Universidad de Talca, tiene por finalidad la divulgación de la actividad de investigación de sus académicos. Se reciben trabajos científicos originales, o aplicaciones que muestren contribuciones adicionales, en el área de las ciencias económicas y empresariales, incluyendo trabajos terminados o comunicaciones de trabajos en etapa de realización.

\section{Autores}

WPS está limitada a los trabajos donde a lo menos uno de los autores esté adscrito a la Facultad de Ciencias Empresariales de la Universidad de Talca.

\section{Condiciones}

Antes de la admisión de un trabajo para su publicación es condición indispensable que el autor haya presentado su trabajo en un evento de carácter nacional o internacional.

\section{Formato}

El documento debe presentarse en papel y en formato MS Word (.doc) para el cuerpo del trabajo y en Excel (.xls) para tablas y figuras; interlineado 1,5 líneas, letra Times New Roman tamaño 11 , con márgenes de $2,5 \mathrm{~cm}$ por lado.

El número máximo de páginas (incluyendo todo tipo de "apéndices") será 25 . Todas las páginas deben llevar el número al pie y en posición central.

Las "notas" pueden ir a pie de página o al final. Las tablas y gráficos pueden intercalarse en el texto o añadirse al final. Los "apéndices", se colocarán al final convenientemente numerados.

Las referencias bibliográficas se colocarán a continuación del texto principal (antes de los apéndices y otros complementos). En el texto principal se indicará sólo el nombre del autor y año de la obra). En la página de referencias se indicarán los datos completos de identificación según los siguientes modelos. (a) Libro: KRUGMAN, P.R., \& M. OBSTFELD. (2000): Economía internacional: teoría y política. $5^{a}$ ed. Addison Wesley, Madrid, España. 784 p. (b) Artículo en libro: PETTERSON. W. (1979): "Total factor productivity in the UK: a disaggregated analysis", en PATTERSON y SCOTT (eds): The measurement of capital, London, Macmillan, p. 212-225. (c) Artículo de revista: BULL, G., \& HARKIN, Z. (2000): "Developing a carbon accounting framework for forests", The Journal of Forestry, June, 98(2): 4-6. (d) Tesis y Memorias: AMAYA, P., y ROMERO, C. (2001): "Evaluación económica de la adicionalidad de captura de carbono en recursos forestales, sector Vilches Alto, Región del Maule". Memoria de Ingeniero Comercial. Universidad de Talca, Facultad de Ciencias Empresariales, Talca, Chile. 84 p. (e) Material electrónico: DEVANEY S.A., \& Z. CHEN. "Job satisfaction of recent graduates in financial services", Purdue University. Available at: http://www.bls.gov/opub/cwc/ cm20030522ar01p1.htm. Accessed 31 July 2003.

\section{Evaluación}

Los trabajos enviados serán revisados por dos evaluadores. Aún cuando el autor puede sugerir al Director de la SWP algunos nombres de evaluadores, el proceso de revisión por pares es anónimo y confidencial. La aceptación o rechazo de un artículo lo decide finalmente el Comité Editor. 